\title{
Fertility measures in Polish Black-and-White cattle. 4. Phenotypic and genetic correlations between fertility measures and type traits ${ }^{*}$
}

\author{
W. Jagusiak ${ }^{1}$ \\ Agricultural University of Cracow, Department of Genetics and Animal Breeding \\ Mickiewicza 24/28, 30-059 Kraków, Poland
}

(Received 21 June 2006; revised version 7 September 2006; accepted 6 November 2006)

\begin{abstract}
Phenotypic and genetic correlations between fertility measures and conformation traits were estimated. Data were records of 38,274 cows; the records consisted of eight fertility traits, five descriptive type traits, height and rump and fourteen linearly scored conformation traits. The correlations were estimated using REML based on linear animal model. The phenotypic correlations between fertility and descriptive type traits were in general low or close to zero. The largest were obtained for non-return rates with central ligament $(0.055)$, body depth (-0.066), chest width (-0.079) and rump width (-0.082). The genetic correlations of age at first insemination and age at conception with descriptive type traits, height at rump, and linearly scored udder traits were negative and ranged from -0.014 to -0.224 . Age at first insemination and age at conception correlated positively with rump width and chest width. The genetic correlations between non-return rates and most of the conformation traits were low. The largest correlations between descriptive type traits and interval fertility measures were obtained for conformation and dairy character with service period (0.361) and days open (0.313). Among linearly scored type traits, large correlations were found for rear udder height, udder width, and central ligament with service period and days open (from 0.225 to 0.422 ). All interval traits showed negative correlations with fore udder attachment, and small correlations with rump traits, body depth and chest width.
\end{abstract}

KEY WORDS: dairy cattle, fertility, type traits, genetic correlations, linear animal model

\section{INTRODUCTION}

The main reason for the decline in cow fertility in recentyears has been the selection mainly for milk production traits (Roxström et al., 2001; Royal et al., 2002). Large

\footnotetext{
*Supported by the State Committee for Scientific Research, Grant No. 2 P06D 03827

${ }^{1}$ Corresponding author: e-mail: rzjagusi@cyf-kr.edu.pl
} 
and moderate genetic correlations between yield and type traits (Jagusiak, 2005c) caused a correlated response and, in consequence, large genetic trends observed for many conformation traits (Hansen, 2000). Presently, type traits are considered very important because of their genetic relations with production and functional traits. The heritability of many type traits is larger than that of most functional traits (Żarnecki et al., 2003; Jagusiak, 2005c), and selection for conformation may lead to a correlated response in fertility. Moreover, type traits are easy to record and can be measured for young animals before yield and fertility measures are available. In some indexes, type traits can be used to predict the fertility of young animals; in others both type and fertility traits can be used as early indicators of longevity (Sewalem et al., 2004; Tsuruta et al., 2005).

Rump conformation is critical to cow reproduction because high pin bones and upward rump angle not only affect the parturition process but also increase infection risk and reduce fertility. Wall et al. (2005) found a negative genetic correlation of -0.16 between linear score of rump angle and calving interval; a positive and smaller correlation was reported by Pryce et al. (2000). Shapiro and Swanson (1991) did not detect any relations between rump traits and fertility measures.

Another group of type traits with a large impact on reproduction comprises descriptive and linear traits of legs and feet. Bad leg conformation strongly affects animal welfare, and feet defects lead to diseases and lameness. Perez-Cabal et al. (2006) estimated genetic correlations of feet and legs with fertility measures ranging from 0.07 to 0.17 . Estimates of genetic correlations between calving interval and leg traits published by Pryce et al. (2000) were 0.19 for rear leg set and -0.20 for foot angle.

Antagonistic genetic correlations of dairy character with fertility measures were shown by Pryce et al. (2000) and Dechow et al. (2004). The reason for large and unfavourable genetic correlations between dairy character and interval fertility traits (from 0.40 to 0.47 ) is the large genetic correlation between dairy character and milk production.

The aim of this study was to estimate genetic and phenotypic correlations between type and fertility measures and to identify the conformation traits most useful for early prediction of cow fertility.

\section{MATERIAL AND METHODS}

The genetic parameters were estimated based on the data set described by Jagusiak (2005a). The cow records contained twenty type traits and eight fertility traits: NR56 (non-return rate to 56th day), NR72 (non-return rate to 72nd day), two age traits (age at first insemination and age at conception), service period (number 
of days from first insemination to conception), days to first service (interval from calving to first service), days open (interval from calving to conception), calving interval (days) (interval from calving to the next calving). Fertility measures were characterized in detail in previous papers (Jagusiak, 2005a,b).

Different names and definitions of type traits are used in different countries (http://www-interbull.slu.se/); the terminology used in this paper follows Żarnecki et al. (2000). The type traits are listed in Table 1; size, conformation and dairy

Table 1. Means and standard deviations of type and fertility traits

\begin{tabular}{|c|c|c|c|c|}
\hline No. & Trait & $\mathrm{n}$ & $\overline{\mathrm{x}}$ & SD \\
\hline 1. & Size, $50-100$ scale & 38274 & 79.50 & 5.30 \\
\hline 2. & Conformation and dairy character, $50-100$ scale & 38274 & 78.13 & 4.32 \\
\hline 3. & Legs and feet, $50-100$ scale & 38274 & 78.05 & 4.01 \\
\hline 4. & Udder, $50-100$ scale & 38274 & 76.61 & 4.49 \\
\hline 5. & Final score, $50-100$ scale & 38274 & 78.93 & 4.26 \\
\hline 6. & Height at rump, $\mathrm{cm}$ & 38274 & 138.90 & 4.06 \\
\hline 7. & Body depth, 1-9 scale & 38274 & 6.41 & 1.17 \\
\hline 8. & Chest width, 1-9 scale & 38274 & 5.60 & 1.18 \\
\hline 9. & Rump angle, 1-9 scale & 38274 & 5.27 & 1.13 \\
\hline 10. & Rump width, 1-9 scale & 38274 & 5.59 & 1.19 \\
\hline 11. & Rear leg set, 1-9 scale & 38274 & 5.51 & 1.02 \\
\hline 12. & Foot angle, 1-9 scale & 38274 & 5.04 & 1.15 \\
\hline 13. & Fore udder attachment, 1-9 scale & 38274 & 5.86 & 1.22 \\
\hline 14. & Rear udder height, 1-9 scale & 38274 & 5.61 & 1.16 \\
\hline 15. & Central ligament, 1-9 scale & 38274 & 5.69 & 1.40 \\
\hline 16. & Udder depth, 1-9 scale & 38274 & 5.76 & 1.35 \\
\hline 17. & Udder width, 1-9 scale & 38274 & 5.68 & 1.17 \\
\hline 18. & Fore teat placement, 1-9 scale & 38274 & 4.86 & 1.16 \\
\hline & Teat length, 1-9 scale & 38274 & 4.73 & 1.15 \\
\hline 20. & Dairy character, 1-9 scale & 38274 & 6.12 & 1.17 \\
\hline 21. & Age at first insemination, days & 38274 & 537.6 & 75.5 \\
\hline 22. & Age at conception, days & 38274 & 556.8 & 79.0 \\
\hline 23. & NR56, 0,1 scale & 38274 & 0.73 & 0.39 \\
\hline & NR72, 0,1 scale & 38274 & 0.69 & 0.42 \\
\hline & Calving interval, days & 22549 & 409.8 & 77.4 \\
\hline & Days open, days & 22549 & 132.1 & 77.1 \\
\hline & Days to first service, days & 22549 & 79.3 & 35.2 \\
\hline & Service period, days & 38274 & 27.5 & 53.8 \\
\hline
\end{tabular}

description of type traits in Żarnecki et al. (2000)

character, legs and feet, and udder conformation were the descriptive traits, scored on a scale from 50 to 100 . Final score was computed as a weighted average based on the previous four traits, and height at rump was the only trait measured in $\mathrm{cm}$. 
All remaining traits were scored on a linear scale from 1 to 9 , and can be divided into groups describing udder ( 7 traits), legs ( 2 traits), rump (2 traits) and size (2 traits).

Finally a data set containing fertility and conformation records of 38,274 cows born between 1996 and 2000 was created. Means of the descriptive traits ranged from 76.61 for udder to 79.50 for size (Table 1). The standard deviation for size was the largest (5.30). Average measures for linearly scored traits were between 4.73 and 6.41 , and standard deviations ranged from 1.02 for rear legs to 1.40 for central ligament. Type traits were scored between days 15 and 180 of cow lactation, and the term between them was divided into eleven 15-day stages of lactation. Each conformation record was assigned to one lactation stage. Calving interval, days open and days to first service were available for 22,549 cows with completed second lactation; 1,524 herd-year subclasses for fertility measures and 2,395 herdyear-season-classifier subclasses for conformation traits were formed.

(Co)variance components of the fertility traits were estimated by restricted maximum likelihood (REML) (Misztal and Perez-Enciso, 1993):

$$
\mathbf{y}=\mathbf{X b}+\mathbf{Z Q g}+\mathbf{Z u}+\mathbf{e}
$$

where $\mathbf{y}$ is the vector of observations, and $\mathbf{g}$ is the vector of fixed effects of genetic groups. Vector $\mathbf{b}$ is the vector of fixed effects, and for fertility measures consists of herd-year of calving and month of calving. Regression on age of first calving was applied for days to first service, service period, days open and calving interval. Vector $\mathbf{b}$ for type traits consists of herd-year-season-classifier subclass, stage of lactation subclass and regression on age at calving. Vector $\mathbf{u}$ is the vector of additive animal genetic effects, $\mathbf{e}$ is the vector of residual error, and $\mathbf{X}, \mathbf{Z}$ and $\mathbf{Q}$ are coincidence matrices.

Both $\mathbf{u}$ and $\mathbf{e}$ are normally distributed with the expectations and (co)variance matrices:

$$
\mathbf{E}=\left[\begin{array}{l}
\mathbf{u} \\
\mathbf{e}
\end{array}\right]=\left[\begin{array}{l}
\mathbf{0} \\
\mathbf{0}
\end{array}\right], \quad \mathbf{V}\left[\begin{array}{l}
\mathbf{u} \\
\mathbf{e}
\end{array}\right]=\left[\begin{array}{ll}
\mathbf{G} & \mathbf{0} \\
\mathbf{0} & \mathbf{R}
\end{array}\right]
$$

where matrix $\mathbf{G}$ is equal to $\mathbf{A} \otimes \mathbf{G}_{0}$, matrix $\mathbf{R}$ is equal to $\mathbf{I} \otimes \mathbf{R}_{0}, \mathbf{A}$ is the relationship matrix, $\mathbf{G}_{\mathbf{0}}$ the genetic (co)variance matrix between traits, $\mathbf{R}_{\mathbf{0}}$ is the residual (co)variance matrix between traits, and $\otimes$ is the Kronecker product.

The number of all animals including parents and known grandsires was 71,356. Genetic groups were created according to Westell et al. (1988). Animals with unknown parents were assigned to phantom parent groups by birth year and percentage of Holstein-Friesian (HF) genes. Five groups for male and eight for female phantom parents were created.

Type traits were divided into several groups, and (co)variances between each group and fertility measures were estimated separately. First the (co)variances of 
descriptive traits were computed; genetic correlations between fertility measures and final score were estimated separately because of linear dependencies between final score and other descriptive traits. The second group of type traits consisted of rump traits, body depth and chest width; the third group consisted of five udder traits. Leg traits, teat placement and length and dairy character were included in the fourth group.

Standard errors of genetic correlation estimates were computed according to Dodenhoff et al. (1998).

\section{RESULTS}

Phenotypic correlations between fertility traits and conformation

Phenotypic correlations between fertility and type traits were in general low or close to zero (Table 2). The largest correlations were found for non-return

Table 2. Genetic and phenotypic (in brackets) correlations between fertility measures and composite conformation traits

\begin{tabular}{lccccc}
\hline Trait & Size & $\begin{array}{c}\text { Conformation } \\
\text { and dairy character }\end{array}$ & $\begin{array}{c}\text { Legs and } \\
\text { feet }\end{array}$ & Udder & $\begin{array}{c}\text { Final } \\
\text { score }\end{array}$ \\
\hline Age at first insemination & -0.014 & -0.116 & -0.089 & -0.167 & -0.138 \\
& $(0.007)$ & $(0.005)$ & $(-0.006)$ & $(-0.006)$ & $(0.002)$ \\
Age at conception & -0.180 & -0.085 & -0.154 & -0.156 & -0.224 \\
& $(-0.011)$ & $(0.001)$ & $(-0.006)$ & $(-0.001)$ & $(-0.009)$ \\
NR56 & -0.041 & -0.029 & 0.155 & 0.079 & -0.006 \\
& $(-0.056)$ & $(-0.033)$ & $(0.008)$ & $(0.000)$ & $(-0.036)$ \\
NR72 & -0.028 & -0.042 & 0.182 & 0.074 & -0.008 \\
& $(-0.066)$ & $(-0.041)$ & $(0.009)$ & $(-0.002)$ & $(-0.044)$ \\
Days to first service & 0.074 & 0.001 & -0.057 & -0.025 & 0.002 \\
& $(-0.011)$ & $(-0.006)$ & $(-0.016)$ & $(0.018)$ & $(-0.001)$ \\
Service period & 0.175 & 0.361 & -0.038 & 0.238 & 0.259 \\
& $(0.002)$ & $(0.010)$ & $(-0.006)$ & $(0.020)$ & $(0.014)$ \\
Days open & 0.180 & 0.313 & 0.029 & 0.209 & 0.244 \\
& $(-0.004)$ & $(0.005)$ & $(-0.012)$ & $(0.025)$ & $(0.011)$ \\
Calving interval & 0.167 & 0.225 & 0.124 & 0.159 & 0.172 \\
& $(-0.006)$ & $(0.002)$ & $(0.011)$ & $(0.036)$ & $(0.015)$ \\
\hline
\end{tabular}

estimated SE of $r_{g}$ ranged from 0.08 to 0.19 
rates with central ligament (0.055) (Table 3), body depth (-0.066) (Table 4), chest width (-0.079) (Table 4) and rump width (-0.082) (Table 4). Age at first insemination and age at conception showed very small phenotypic correlations with conformation. The correlation between age at first insemination and rear leg set was 0.023 (Table 5), the correlation with rump width was 0.028 (Table 4), and the majority of other correlations were less than 0.01 .

Phenotypic correlations between calving interval and udder conformation traits ranged from 0.02 (Table 3 ) for fore udder attachment to 0.036 for overall udder score (Table 2). The correlation between days open and rear udder height was even higher (0.039) (Table 3). All remaining correlations between interval fertility and type traits were smaller.

Table 3. Genetic and phenotypic (in brackets) correlations between fertility measures and linear udder conformation traits

\begin{tabular}{lccccc}
\hline Trait & $\begin{array}{c}\text { Fore udder } \\
\text { attachment }\end{array}$ & $\begin{array}{c}\text { Rear udder } \\
\text { height }\end{array}$ & $\begin{array}{c}\text { Central } \\
\text { ligament }\end{array}$ & $\begin{array}{c}\text { Udder } \\
\text { depth }\end{array}$ & $\begin{array}{c}\text { Udder } \\
\text { width }\end{array}$ \\
\hline Age at first insemination & 0.150 & -0.184 & -0.221 & -0.105 & -0.050 \\
& $(0.012)$ & $(-0.012)$ & $(-0.038)$ & $(-0.019)$ & $(0.010)$ \\
Age at conception & -0.058 & -0.120 & -0.084 & -0.142 & -0.020 \\
& $(-0.005)$ & $(0.008)$ & $(-0.006)$ & $(0.005)$ & $(-0.001)$ \\
NR56 & -0.136 & 0.064 & 0.169 & 0.155 & -0.133 \\
& $(-0.026)$ & $(0.012)$ & $(0.055)$ & $(0.039)$ & $(-0.031)$ \\
NR72 & -0.108 & 0.035 & 0.185 & 0.169 & -0.192 \\
& $(-0.027)$ & $(0.012)$ & $(0.054)$ & $(0.043)$ & $(-0.038)$ \\
Days to first service & -0.304 & 0.114 & -0.020 & -0.064 & 0.068 \\
& $(-0.005)$ & $(0.037)$ & $(0.018)$ & $(0.009)$ & $(0.020)$ \\
Service period & -0.173 & 0.364 & 0.225 & 0.002 & 0.294 \\
& $(0.002)$ & $(0.026)$ & $(0.018)$ & $(-0.003)$ & $(0.028)$ \\
Days open & -0.365 & 0.422 & 0.258 & -0.038 & 0.352 \\
& $(-0.002)$ & $(0.039)$ & $(0.023)$ & $(0.003)$ & $(0.032)$ \\
Calving interval & -0.234 & 0.353 & 0.176 & 0.109 & 0.091 \\
& $(0.020)$ & $(0.028)$ & $(0.027)$ & $(0.022)$ & $(0.024)$ \\
\hline
\end{tabular}

estimated SE of $\mathrm{r}_{\mathrm{g}}$ ranged from 0.11 to 0.23

Genetic correlations between heifer fertility and type traits

Correlations between age traits and descriptive type traits were in general negative (Table 2). The largest genetic correlations were found for final score 
$(-0.138$ with age at first insemination and -0.224 with age at conception) and udder conformation ( -0.167 and -0.156 , respectively). The correlation was also negative between age at conception and legs and feet (-0.154).

Linearly scored udder traits were also negatively correlated with age traits (Table 3). The highest correlations were between age at first insemination and central ligament $(-0.221)$ and rear udder height $(-0.184)$. The correlations were negative between udder depth and both age at first insemination (-0.105) and age at conception (-0.142). Genetic correlation between age at conception and height at rump amounted to -0.203 (Table 4).

The negative correlations of age traits with height at rump and descriptive type traits indicate that daughters of parents selected for better udder conformation and final score are likely to conceive earlier. Similarly, the negative correlations between age traits and linear udder scores indicate favourable dependencies. On the other hand, it may be that dams with better breeding value for conformation have daughters that are earlier inseminated for the first time and conceive earlier.

Age traits were correlated positively with rump width $(0.263$ with age at first insemination and 0.254 with age at conception) and chest width (0.245 and 0.191 ,

Table 4. Genetic and phenotypic (in brackets) correlations between fertility measures, body depth, chest width and rump conformation traits

\begin{tabular}{lccccc}
\hline Trait & $\begin{array}{c}\text { Height at } \\
\text { rump }\end{array}$ & $\begin{array}{c}\text { Body } \\
\text { depth }\end{array}$ & $\begin{array}{c}\text { Chest } \\
\text { width }\end{array}$ & $\begin{array}{c}\text { Rump } \\
\text { angle }\end{array}$ & $\begin{array}{c}\text { Rump } \\
\text { width }\end{array}$ \\
\hline Age at first insemination & -0.035 & 0.004 & 0.245 & -0.104 & 0.263 \\
& $(0.005)$ & $(0.011)$ & $(0.022)$ & $(0.006)$ & $(0.028)$ \\
Age at conception & -0.203 & -0.049 & 0.191 & 0.026 & 0.254 \\
& $(-0.009)$ & $(-0.012)$ & $(-0.004)$ & $(0.005)$ & $(-0.011)$ \\
NR56 & -0.015 & -0.250 & -0.264 & 0.187 & -0.282 \\
& $(-0.051)$ & $(-0.059)$ & $(-0.068)$ & $(0.010)$ & $(-0.078)$ \\
NR72 & 0.003 & -0.262 & -0.263 & 0.169 & -0.270 \\
& $(-0.060)$ & $(-0.066)$ & $(-0.079)$ & $(0.010)$ & $(-0.082)$ \\
Days to first service & 0.092 & -0.056 & -0.041 & 0.112 & -0.058 \\
& $(-0.011)$ & $(-0.019)$ & $(-0.021)$ & $(0.005)$ & $(-0.007)$ \\
Service period & 0.153 & 0.059 & -0.049 & -0.093 & -0.050 \\
& $(-0.002)$ & $(-0.004)$ & $(-0.004)$ & $(-0.011)$ & $(-0.001)$ \\
Days open & 0.184 & 0.052 & -0.085 & 0.023 & -0.079 \\
& $(-0.006)$ & $(-0.013)$ & $(-0.015)$ & $(-0.005)$ & $(-0.004)$ \\
Calving interval & 0.101 & -0.061 & -0.061 & 0.128 & -0.165 \\
& $(-0.008)$ & $(-0.009)$ & $(-0.009)$ & $(-0.001)$ & $(-0.011)$ \\
\hline
\end{tabular}

estimated SE of $r_{g}$ ranged from 0.05 to 0.13 
Table 5. Genetic and phenotypic (in brackets) correlations between fertility measures, dairy character, feet and teat conformation

\begin{tabular}{lccccc}
\hline Trait & $\begin{array}{c}\text { Rear leg } \\
\text { set }\end{array}$ & $\begin{array}{c}\text { Foot } \\
\text { angle }\end{array}$ & $\begin{array}{c}\text { Fore teat } \\
\text { placement }\end{array}$ & $\begin{array}{c}\text { Teat } \\
\text { length }\end{array}$ & $\begin{array}{c}\text { Dairy } \\
\text { character }\end{array}$ \\
\hline Age at first insemination & 0.076 & 0.006 & -0.173 & 0.035 & -0.153 \\
& $(0.023)$ & $(0.004)$ & $(-0.014)$ & $(0.001)$ & $(0.001)$ \\
Age at conception & 0.110 & -0.100 & -0.119 & 0.182 & -0.091 \\
& $(0.007)$ & $(-0.007)$ & $(-0.001)$ & $(0.000)$ & $(0.006)$ \\
NR56 & -0.159 & 0.087 & 0.123 & 0.065 & -0.053 \\
& $(-0.025)$ & $(-0.018)$ & $(0.013)$ & $(-0.013)$ & $(-0.018)$ \\
NR72 & -0.197 & 0.098 & 0.131 & 0.066 & -0.069 \\
& $(-0.027)$ & $(-0.019)$ & $(0.010)$ & $(-0.013)$ & $(-0.022)$ \\
Days to first service & 0.029 & -0.077 & -0.193 & -0.065 & 0.014 \\
& $(0.008)$ & $(-0.008)$ & $(0.005)$ & $(-0.001)$ & $(0.009)$ \\
Service period & 0.333 & -0.172 & -0.028 & -0.100 & 0.398 \\
& $(0.007)$ & $(0.005)$ & $(0.005)$ & $(0.003)$ & $(0.018)$ \\
Days open & 0.241 & -0.036 & -0.129 & -0.096 & 0.304 \\
& $(0.008)$ & $(0.001)$ & $(0.006)$ & $(0.003)$ & $(0.019)$ \\
Calving interval & 0.187 & 0.058 & -0.094 & 0.027 & 0.284 \\
& $(-0.021)$ & $(0.003)$ & $(0.014)$ & $(0.006)$ & $(0.008)$ \\
\hline
\end{tabular}

estimated SE of $\mathrm{r}_{\mathrm{g}}$ ranged from 0.12 to 0.25

respectively) (Table 4). The positive correlations suggest that cows with higher breeding values for rump and chest have daughters that conceive later. In fact, the most desirable score for rump traits and chest width is not 9 but 5 or 6 , and a positive correlation does not have to indicate an unfavourable dependence.

The genetic correlations between non-return rates and most of the conformation traits were low. The highest-correlated descriptive type trait was legs and feet $(0.155$ for NR56 and 0.182 for NR72) (Table 2). The correlations between non-return rates and final score were close to zero. A higher non-return rate means that more cows conceive after first insemination; therefore, positive correlations between non-return rates and legs and feet imply that daughters of dams with better legs are less likely to return to AI service. Positive, favourable correlations of non-return rates were found for central ligament ( 0.169 for NR56 and 0.185 for NR72) and udder depth ( 0.155 for NR56 and 0.169 for NR72), whereas the correlations for the remaining udder traits were low or close to zero (Table 3).

The negative correlations between non-return rates and chest width, body depth and rump traits suggest that progeny of cows of smaller size and a narrow rather than wide rump are more likely to conceive at the first insemination (Table 4). 
Table 5 shows the correlations between non-return rates and rear leg set (-0.159 for NR56 and -0.197 for NR72). The optimal value for rear leg set score is 5; the low negative correlations with non-return rates may suggest that straight legs are less undesirable than sickled legs.

\section{Genetic correlations between interval fertility traits and conformation}

Most of the genetic correlations between interval fertility traits and descriptive type traits were positive, meaning that cows with better type scores tend to have longer intervals (Table 2). The correlations were largest for conformation and dairy character with service period (0.361) and days open (0.313). Udder and final score were also correlated with service period and days open (all correlations $>0.2$ ). Slightly lower correlations were obtained for size $(<0.2)$, and legs and feet were not correlated with service period and days open. Correlations between days to first service and interval measures of fertility were close to zero. Calving interval consists of days open and gestation length. The variation of gestation length is quite small; the correlations between calving interval and type traits are similar to these between days open and type traits.

The genetic correlations between type traits and interval fertility measures were largest in the group of linear scored udder traits (Table 3). The correlations were highest for rear udder height with service period (0.364) and days open (0.422). Correlations were also large for udder width ( 0.294 and 0.352 , respectively) and for central ligament ( 0.225 and 0.258 , respectively). All interval traits were negatively correlated with fore udder attachment. The correlations ranged from -0.173 for service period to -0.365 for days open.

Rump traits, body depth and chest width had low correlations with interval fertility measures (Table 4). The largest correlation was between height at rump and days open (0.184). Genetic correlations were higher between rear leg set and service period (0.333) and days open (0.241) (Table 5). Both correlations are positive; therefore, cows with more sickled rear legs are likely to have a longer service period and in consequence more days open and longer calving interval. There were also large positive correlations between dairy character and service period (0.398), days open (0.304) and calving interval (0.284).

\section{DISCUSSION}

Negative genetic trends in fertility traits have been observed in Holstein populations in recent years. Hare et al. (2006) estimated trends in various breeds of American dairy cattle; in this study the coefficients of linear regression of calving 
interval on year of first calving were 1.10 days longer per year for the Holstein population. Similar trends were obtained for calving intervals in later parities.

Unfavourable genetic correlations between milk production and reproduction traits (Jagusiak, 2006) have been the main reason for fertility decline, but selection for some functional traits may also cause negative changes in fertility. Dependencies between conformation and reproduction have been investigated in several papers published in the past century (Ali et al., 1984; Shapiro and Swanson, 1991). Nowadays, both type and fertility traits are included in many selection indices (Miglior et al., 2005); moreover, both groups of traits are used as early predictors of longevity (Sewalem et al., 2004; Tsuruta et al., 2005); therefore importance of genetic correlations between type and reproduction traits is considered to be very substantial.

Non-return rates and linear type traits are scored into one of several categories. There are two main approaches in analysing such traits; the first one is based on a linear model and assumes a continuous distribution for the trait. The second approach - the threshold model proposed by Gianola and Foulley (1983) - assumes the existence of an underlying continuous variable. The estimates of heritabilities obtained using the threshold model are usually larger than those obtained with the linear model, however, breeding value estimations computed using both models are highly correlated (Weller et al., 1988; Weller and Ron, 1992). In general, threshold models better account for the probable structure of categorical data (Gianola, 1982) but many researchers comparing threshold and linear models on the basis of field data have concluded that threshold models are not superior and require greater computing resources than in a linear model analysis (Hager and Hofer, 1989; Jamrozik et al., 1991; Varona et al., 1999).

\section{Genetic correlations between heifer fertility and type traits}

Heifer fertility traits determine the ability of a heifer to conceive. In many papers they are discussed separately because of the rather low correlations with fertility measures of older cows (Jansen et al., 1987). In this study, age at first insemination and age at conception were in general favourably correlated with type traits. Most of the correlations were negative, implying that cows with better conformation conceived earlier. The favourable trend in age at first calving reported by Hare (2006) is partial confirmation of the beneficial relationship between age and type traits obtained in this study.

In many countries, non-return rates are considered the most important fertility measure, well reflecting the ability to conceive and less dependent on management than age traits. In population of Italian Holsteins, Biffani et al. (2005) obtained a very low genetic correlation between NR56 and angularity 
(0.03). The correlations shown in this paper were also very small but negative. Very low correlations between NR56 and type traits were found by Wall et al. (2005) in British Holsteins. The estimates for rump angle, rump width, rear udder height, udder support, legs and feet and mammary system were 0.02 , $-0.01,0.00,-0.01,-0.01$ and 0.00 , respectively. The correlations estimated in the present paper were larger: for rump width close to -0.3 , for udder support (central ligament) above 0.16 , and for legs and feet above 0.15 . All phenotypic correlations between NR56 and type traits estimated by Wall et al. (2005) were negative, amounting to $-0.01,-0.06,-0.09,-0.09,-0.21$ and -0.13 , respectively.

In some countries, number of inseminations per conception is used instead of non-return rates. Perez-Cabal et al. (2006) investigated the relationships between locomotion type traits and reproduction in the Holstein population of several Spanish regions. The genetic correlations obtained for average number of inseminations per lactation with feet and legs, foot angle, and rear leg set were $0.05,0.07$ and 0.08 , respectively. The estimates in this paper were higher for feet and legs, 0.155 with NR56 and 0.182 with NR72. The correlations between nonreturn rates and foot angle were similar to the estimates published by Perez-Cabal et al. (2006).

\section{Genetic correlations between interval fertility and type traits}

Interval measures are another group of fertility measures. Some of them such as service period reflect the ability of a cow to conceive; others such as days to first service reflect the ability of a cow to recycle. Days open consists of these two intervals and can be treated as a composite trait. Days open and gestation length are parts of the calving interval. The standard deviation of number of pregnancy days is quite small; therefore, calving interval depends mainly on number of days open.

Biffani et al. (2005) obtained large genetic correlations between angularity and calving interval (0.38) and between angularity and days to first service (0.36). All residual correlations were close to zero. Dechow et al. (2004) showed a large genetic correlation between days open and dairy form (angularity) showed in the population of American Holsteins scored for type in 1997-2000. The genetic and phenotypic correlations were 0.40 and 0.06 , respectively.

The estimate of the genetic correlation between calving interval and angularity obtained in this paper was lower (0.284), but the correlations of days open and service period with angularity were above 0.3 . Number of days to first service was not correlated with angularity.

Olori et al. (2003) investigated the relationships of calving interval with foot angle and udder depth. The genetic correlations were small: 0.14 and -0.01 , 
respectively. The correlations between calving interval and foot angle were larger in second and third parities (-0.11 and -0.38 , respectively). The genetic correlations of calving interval with feet and legs, foot angle and rear leg set shown by Perez-Cabal et al. (2006) were $0.12,0.17$ and 0.07 , respectively. The estimates of correlations between calving interval and several type traits published by Wall et al. (2005) were very low: for rump angle, rump width, rear udder height, udder support, legs and feet and mammary system they were $-0.03,0.00,0.020 .03,0.00$ and 0.04 , respectively. All phenotypic correlations were also close to zero.

\section{CONCLUSIONS}

In general, the estimates shown in this paper were in the range of correlations published by other authors. Interval fertility traits are better correlated genetically with type traits than with non-return rates and age fertility traits. Large relationships of calving interval and days open were found for rear leg set and descriptive type traits. Most of the mentioned type traits could be included in a fertility index as additional correlated traits. Body depth, chest width and rump traits showed the highest correlations with non-return rates. These traits could be very useful in evaluation of breeding value for NR56 and NR72, because of the low heritability of non-return rates.

\section{REFERENCES}

Ali T.E., Burnside E.B., Schaeffer L.R., 1984. Relationship between external body measurements and calving difficulties in Canadian Holstein-Friesian cattle. J. Dairy Sci. 67, 3034-3044

Biffani S., Marusi M., Biscarini F., Canavesi F., 2005. Developing a genetic evaluation for fertility using angularity and milk yield as correlated traits. National and international genetic evaluations for fertility (1). Uppsala (Sweden). Interbull Bull. No. 33, pp. 63-66

Dechow D., Rogers G.W., Klei L., Lawlor T.J., VanRaden P.M., 2004. Body condition scores and dairy form evaluations as indicators of days open in US Holsteins. J. Dairy Sci. 87, 3534-3541

Dodenhoff J., Van Vleck L.D., Kachman S.D., Koch R.M., 1998. Parameter estimates for direct, maternal, and grandmaternal genetic effects for birth weight and weaning weight in Hereford cattle. J. Anim. Sci. 76, 2521-2527

Gianola D., 1982. Theory and analysis of threshold characters. J. Anim. Sci. 54, 1079-1096

Gianola D., Foulley J.L., 1983. Sire evaluation for ordered categorical data with a threshold model. Genet. Sel. Evol. 15, 201-223

Hager C., Hofer A., 1989. Correlations between breeding values of dairy sires for frequency of dystocia evaluated by a linear and non-linear method. J. Anim. Sci. 67, Suppl. 1, 88 (Abstr.)

Hansen L.B., 2000. Consequences of selection for milk yield from a geneticist's viewpoint. J. Dairy Sci. $83,1145-1150$

Hare E., Norman H. D., Wright J.R., 2006. Trends in calving ages and calving intervals for dairy cattle breeds in the United States. J. Dairy Sci. 89, 365-370

Jagusiak W., 2005a. Fertility measures in Polish Black-and-White cattle. 1. Genetic parameters of heifer fertility traits. J. Anim Feed Sci. 14, 423-433 
Jagusiak W., 2005b. Fertility measures in Polish Black-and-White cattle. 2. Genetic parameters of interval measures. J. Anim Feed Sci. 14, 435-444

Jagusiak W., 2005c. Genetic correlations between milk production traits and break-down conformation traits in Black-and-White cattle (in Polish). Rocz. Nauk. Zoot., Supl., 22, 525-528

Jagusiak W., 2006. Fertility measures in Polish Black-and-White cattle. 3. Phenotypic and genetic correlations between fertility measures and milk production traits. J. Anim Feed Sci. 15, 371-380

Jamrozik J., Schaeffer L.R., Burnside E.B., Sullivan B.P., 1991. Threshold models applied to Holstein conformation traits. J. Dairy Sci. 74, 3196-3201

Jansen J., van der Werf J., De Boer W., 1987. Genetic relationships between fertility traits for dairy cows in different parities. Livest. Prod. Sci. 17, 337-349

Miglior F., Muir B.L., Van Doormaal B.J., 2005. Selection indices in Holstein cattle of various countries. J. Dairy Sci. 88, 1255-1263

Misztal I., Perez-Enciso M., 1993. Sparse matrix inversion for restricted maximum likelihood estimation of varince componenets by expectation-maximization. J. Dairy Sci. 76, 1479-1483

Olori V.E., Pool M.H., Calus M.P.L., Cromie A.R., Veerkamp R.F., 2003. Joint evaluation of survival and fertility in dairy cattle with a linear model. Longevity Trait Aspects. Beltsville (USA). Interbull Bull. No. 30, pp. 20-64

Pérez-Cabal M.A., García C., González-Recio O., Alenda R., 2006. Genetic and phenotypic relationships among locomotion type traits, profit, production, longevity, and fertility in Spanish dairy cows. J. Dairy Sci. 89, 1776-1783

Pryce J.E., Coffey M.P., Brotherstone S., 2000. The genetic relationship between calving interval, body condition score and linear type and management traits in registered Holsteins. J. Dairy Sci. 83, 2664-2671

Roxström A., Strandberg E., Berglund B., Emanuelson U., Philipsson J., 2001. Genetic and environmental correlation among female fertility traits and milk production in different parities of Swedish Red and White dairy cattle. Acta Agr. Scand., Sect. A., Anim. Sci. 51, 7-14

Royal M.D., Flint A.P.F., Woolliams J.A., 2002. Genetic and phenotypic relationships among endocrine and traditional fertility traits and production traits in Holstein-Friesian dairy cows. J. Dairy Sci. 85, 958-967

Sewalem A., Kistemaker G.J., Miglior F., Van Doormaal B.J., 2004. Analysis of the relationship between type traits and functional survival in Canadian Holsteins using a Weibull proportional hazards model. J. Dairy Sci. 87, 3938-3946

Shapiro L.S., Swanson L.V., 1991. Relationships among rump and rear leg type traits and reproductive performance in Holsteins. J. Dairy Sci. 74, 2767-2773

Tsuruta S., Misztal I., Lawlor T.J., 2005. Changing definition of productive life in US Holsteins: Effect on genetic correlations. J. Dairy Sci. 88, 1156-1165

Varona L., Misztal I., Bertrand J.K., 1999. Threshold-linear versus linear-linear analysis of birth weight and calving ease using an animal model: comparison of models. J. Anim. Sci. 77, 2003-2007

Wall E., White I.M.S., Coffey M.P., Brotherstone S., 2005. The relationship between fertility, rump angle, and selected type information in Holstein-Friesian cows. J. Dairy Sci. 88, 1521-1528

Weller J., Misztal I., Gianola D., 1988. Genetic analysis of dystocia, and calf mortality in Israeli-Holsteins by threshold and linear models. J. Dairy Sci. 71, 2491-2501

Weller J.I., Ron M., 1992. Genetic analysis of fertility traits in Israeli Holsteins by linear and threshold models. J. Dairy Sci. 75, 2541-2548

Westell R.A., Quaas R.L., Van Vleck L.D., 1988. Genetic groups in animal model. J. Dairy Sci. 71, $1310-1320$

Żarnecki A., Jagusiak W., Trela J., Czaja H., 2000. Sire evaluation for type traits. National Research Institute of Animal Production and Central Animal Breeding Office. Kraków (Poland) 21, 63-70

Żarnecki A., Morek-Kopeć M., Jagusiak W., 2003. Genetic parameters of linearly scored conformation traits of Polish Black-and-White cows. J. Anim Feed Sci. 12, 689-696 